\title{
Effect of alkalinization and ultra-high-pressure homogenization on casein micelles in raw and pasteurized skim milk
}

\section{S. Touhami, A. Marciniak, A. Doyen, (1) and G. Brisson* 중}

Institute of Nutrition and Functional Foods (INAF), Dairy Science and Technology Research Centre (STELA), Department of Food Sciences, Université Laval, Quebec, Quebec, G1V 0A6, Canada

\section{ABSTRACT}

Mechanical and physicochemical treatments of milk induce structural modifications of the casein $(\mathrm{CN})$ micelles, affecting their techno-functional properties in dairy processing. Here, we studied the effect of alkalinization and ultra-high-pressure homogenization (UHPH) on $\mathrm{CN}$ micelles in raw skim milk (rSM) and pasteurized skim milk (pSM). The $\mathrm{pH}$ of both skim milks (approximately 6.7) was adjusted to 8.5 and 10.5 before UHPH at 100, 200, and $300 \mathrm{MPa}$. The structural changes of the $\mathrm{CN}$ micelles during the treatments were assessed using laser diffraction, transmission electron microscopy, and turbidity measurements. Finally, ultracentrifugation $\left(70,000 \times g\right.$ for $1 \mathrm{~h}$ at $\left.20^{\circ} \mathrm{C}\right)$ was carried out to evaluate the protein's distribution between the supernatant (serum phase) and the pellet (colloidal phase) by gel electrophoresis and protein concentration measurement. Alkalinization of both skim milks induced a significant reduction in turbidity, whereas an increase of the average particle size was observed, the effect being more severe in pSM than rSM. At alkaline $\mathrm{pH}$, more proteins were recovered in the serum phase, which suggested that the CN underwent major rearrangements into nonsedimentable $\mathrm{CN}$ forms of various sizes, as confirmed by transmission electron microscopy. The amount of $\mathrm{CN}$ found in the serum phase at $\mathrm{pH} 8.5$ also increased with the UHPH pressure. Although UHPH did not influence the average $\mathrm{CN}$ micelle size at $\mathrm{pH} 6.7$ and 8.5, a pressure-dependent decrease was observed at $\mathrm{pH} 10.5$ for both skim milks. The structural changes of the CN micelles observed in this study throughout the combination of alkalinization and UHPH could be of interest for developing new dairy ingredients with improved functionality.

Key words: skim milk, casein micelle, alkalinization, $\mathrm{UHPH}$

Received May 5, 2021

Accepted November 24, 2021

*Corresponding author: guillaume.brisson@fsaa.ulaval.ca

\section{INTRODUCTION}

Casein micelles are self-associated colloids in milk, with sizes ranging from 50 to $600 \mathrm{~nm}$ in diameter and an average diameter of $150 \mathrm{~nm}$ (Fox and Brodkorb, 2008). Casein micelles consist of 4 classes of phosphoproteins: $\alpha_{\mathrm{S} 1^{-}} \mathrm{CN}, \alpha_{\mathrm{S}^{-}} \mathrm{CN}, \beta-\mathrm{CN}$, and $\kappa-\mathrm{CN}$, which represent $80 \%$ of total proteins in bovine milk (Ahmad et al., 2009). The CN micelle's structure is stabilized by hydrophobic and electrostatic interactions, hydrogen bonding, and colloidal calcium phosphate (CCP; Vaia et al., 2006; Goulding et al., 2020). Changes in the physicochemical environment such as temperature, $\mathrm{pH}$, ionic strength, and water activity lead to changes in $\mathrm{CN}$ micelle integrity throughout the disruption of various chemical interactions (Pelegrine and Gasparetto, 2005; Vaia et al., 2006; McMahon and Oommen, 2008; Madadlou et al., 2009a; Sinaga et al., 2017). Alkalinization of milk has been associated with significant changes in CN micelle size (Vandijk, 1992; Ahmad et al., 2009). However, there are still divergences in the interpretations of the $\mathrm{pH}$ impact on $\mathrm{CN}$ micelle size in the alkaline range. The CN micelle dissociation has been attributed to several effects. The reduction of the hydrophobic interactions among the $\mathrm{CN}$, an increase in electrostatic repulsions, and changes in the mineral balance between the colloidal and the aqueous phases involving calcium and phosphate have been reported (Vaia et al., 2006; Huppertz et al., 2008; Sinaga et al., 2017). However, other authors have shown that alkaline dissociated CN molecules rearranged into highly solvated nonsedimentable aggregates of heterogeneous sizes (Ahmad et al., 2009; Madadlou et al., 2009b).

As the structure of $\mathrm{CN}$ micelles is loosened and becomes more fragile at alkaline $\mathrm{pH}$, the application of mechanical treatment may induce disruption of CN micelles and change their functional properties in milk. Recently, ultra-high-pressure homogenization (UHPH) has been used in the food industry to provide new products by protecting the sensory quality of sensitive components in food products and functional properties, and specific structural characteristics (Patrignani 
and Lanciotti, 2016). The UHPH technology combines the advantages of conventional homogenization such as emulsification and particle size reduction and the possibility of pasteurization with the use of higher pressure, up to $400 \mathrm{MPa}$ (Dumay et al., 2013). In the dairy sector, UHPH has been investigated for inactivating enzymes, viruses, and bacteria and forming stable and homogeneous emulsions. In milk, UHPH treatment induces denaturation and aggregation of whey proteins (WP) and changes in the CN micellar structure and size (Hayes and Kelly, 2003; Sandra and Dalgleish, 2005; Chevalier-Lucia et al., 2011; Zamora and Guamis, 2015). For example, a CN micelle reduction of 5 to $33 \%$ has been reported after UHPH treatments (200-300 MPa; Hayes and Kelly, 2003; Chevalier-Lucia et al., 2011). The changes in the size of the $\mathrm{CN}$ micelles have been attributed to the partial removal of the $\kappa-\mathrm{CN}$ and $\mathrm{a}_{\mathrm{S}}-\mathrm{CN}$ at the micelle surface (Sandra and Dalgleish, 2005; Zamora and Guamis, 2015). However, to our knowledge, no study has been carried out on the effect of UHPH treatments on the CN micelle size and their structural association state at alkaline $\mathrm{pH}$.

The present work aimed to explore the combined effects of UHPH treatment on skim milk (SM) in the alkaline $\mathrm{pH}$ range and the result on CN's structural modifications and change in protein associations and distribution between the colloidal and serum phases. The combination of alkalinization and UHPH could be an efficient way to control the $\mathrm{CN}$ micelle size to develop dairy ingredients with new techno-functional properties.

\section{MATERIALS AND METHODS}

\section{Materials}

Fresh raw whole milk was sourced from a local distributor (Quebec, QC, Canada) and split into 2 batches. One batch was kept raw, and the other half was pasteurized at $72^{\circ} \mathrm{C}$ for $20 \mathrm{~s}$ (Chalinox/Hydro-Québec CFI-25). Raw and pasteurized milk were then skimmed using a Westfalia cream separator (LWA-205, DeLaval) to obtain raw skim milk (rSM) and pasteurized skim milk (pSM). The SM composition was determined using LactoScope FTIR milk analyzer (Table 1; Delta Instruments). Sodium azide $(0.02 \%$; wt/vol) was added to prevent microbial growth.

\section{Methods}

The detailed flowchart of the experimental design is provided in Figure 1.

\section{pH Adjustment}

The initial $\mathrm{pH}$ value of $\mathrm{rSM}$ and $\mathrm{pSM}$ was $6.7 \pm 0.05$. Sodium hydroxide (NaOH, Sigma-Aldrich) 1.0 M was used to adjust the milk's $\mathrm{pH}$ to $8.5 \pm 0.05$ and 10.5 \pm 0.05 . Samples were then stored at $4^{\circ} \mathrm{C}$ for $24 \mathrm{~h}$ to allow $\mathrm{pH}$ equilibration. The $\mathrm{pH}$ was then readjusted to the targeted $\mathrm{pH}(\mathrm{pH} 8.5$ and 10.5) before UHPH treatments. This $\mathrm{pH}$ range was chosen based on the work of Liu and Guo (2008) and Sinaga et al. (2017).

\section{UHPH of Milk}

For each replicate, the $\mathrm{pH}$-adjusted rSM and $\mathrm{pSM}$ were homogenized using one stage UHPH (Nano Debee, model 45-4, Bee International) at 100, 200, and $300 \mathrm{MPa}$. The SM samples were kept at $4^{\circ} \mathrm{C}$ in the inlet reservoir before being forced by the intensifying pump through the UHPH emulsifying cell consisting in a narrow zirconia nozzle $(0.20 \mathrm{~mm}$ diameter, model Z8, Bee International), connected to 12 interaction chambers that increase the cavitation, shear, and turbulence time. The Nano DeBee allowed a reverse flow setup. In this configuration, the fluid was forced to flow back from the interacting chambers toward the nozzle, generating a high shear impact between the opposing streams before exiting through the outlet port located just before the nozzle. The samples were subjected to rapid cooling by a heat exchanger with circulating water at $10^{\circ} \mathrm{C}$, located at the immediate outlet port to minimize any increase in temperature within the processing chamber. Nonhomogenized rSM and pSM were used as control samples.

\section{Ultracentrifugation}

After UHPH, the samples were ultracentrifuged at $70,000 \times g$ for $1 \mathrm{~h}$ at $20^{\circ} \mathrm{C}$ using the Optima XPN-90 ultracentrifuge (Beckman Coulter). The pellets and supernatants were collected and kept frozen until further analyses.

Table 1. Composition of raw (rSM) and pasteurized (pSM) skim milk ${ }^{1}$

\begin{tabular}{lcc}
\hline Item $(\%)$ & rSM & pSM \\
\hline TS & $8.69 \pm 0.31$ & $9.13 \pm 0.31$ \\
Lipids & $0.12 \pm 0.01$ & $0.13 \pm 0.02$ \\
Proteins & $4.28 \pm 0.1$ & $4.63 \pm 0.05$ \\
Lactose & $4.61 \pm 0.1$ & $4.63 \pm 0.05$ \\
\hline
\end{tabular}

${ }^{1}$ Mean \pm SD $(\mathrm{n}=3)$. 

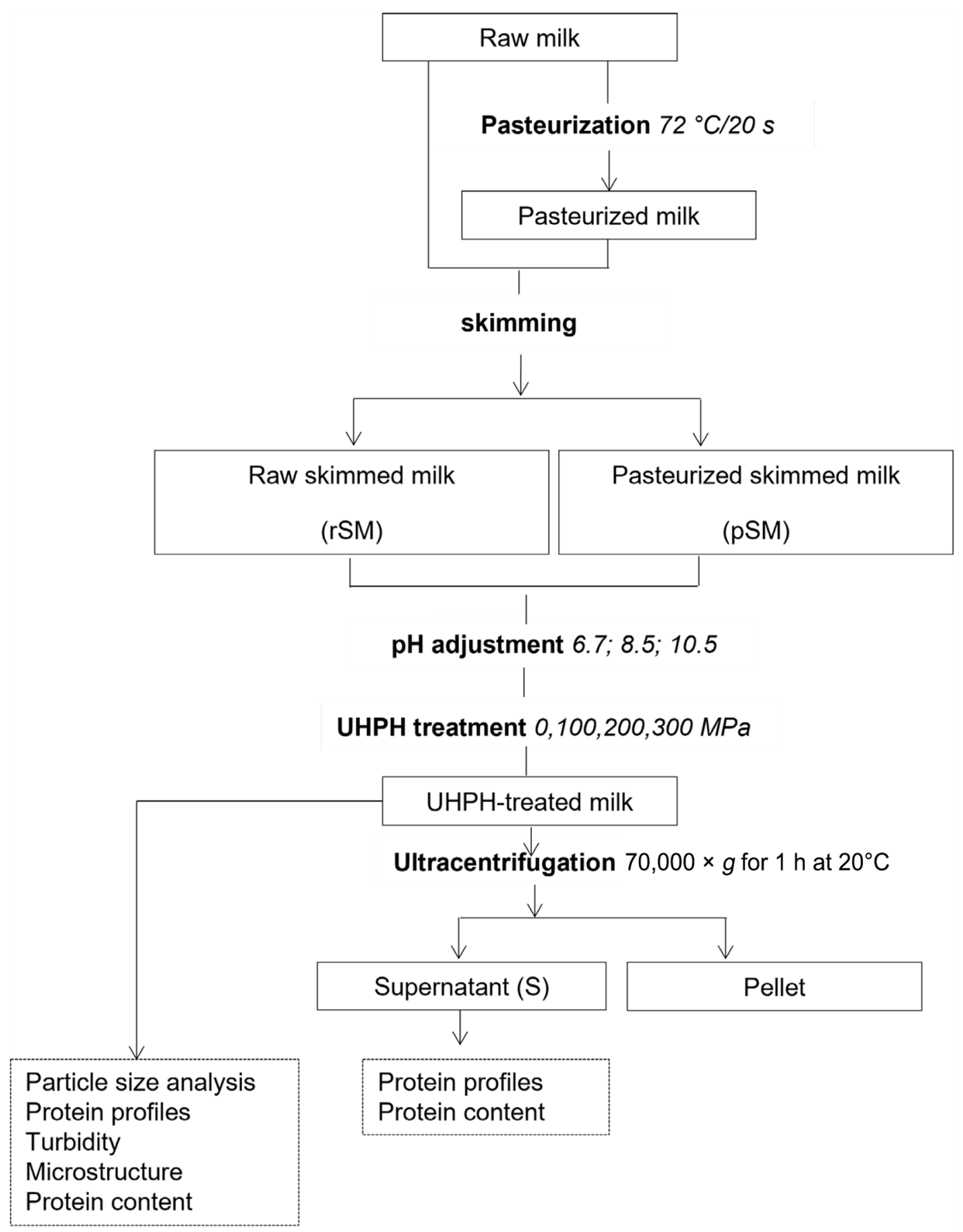

Figure 1. Schematic representation of the experimental design. UHPH = ultra-high-pressure homogenization.

\section{Characterization and Composition}

Particle Size Analysis. Mean particle diameter and particle size distribution (PSD) were measured with a laser diffraction particle size analyzer (Mastersizer 3000, Malvern Instruments) and the analysis was carried out at $23^{\circ} \mathrm{C}$ (Hayes and Kelly, 2003). Refrac- tive indexes were set at 1.39 and 1.33 for $\mathrm{CN}$ micelles and water, respectively (Alexander et al., 2002). The sample particle characteristics are reported by the volume-weighted mean diameter $\left(\mathbf{D}_{4,3}\right)$, the surfaceweighted mean diameter $\left(\mathbf{D}_{3,2}\right)$, and the span value. Each replicate was run 3 times, with 3 measurements per run. 
Transmission Electron Microscopy. Transmission electron microscopy (TEM) was carried out on control and homogenized rSM and $\mathrm{pSM}$ at different $\mathrm{pH}$ values (pH 6.7, 8.5, and 10.5) to examine changes in milk microstructure. Samples were prepared as described by Marciniak et al. (2018). Samples were diluted 10-fold and prepared by successively placing a droplet of the diluted sample and 3\% uranium acetate on 200 mesh nickel grids covered with a Formvar film and air-dried. A Jeol JEM-1230 TEM device operating at $80 \mathrm{kV}$ was used for imaging. A Gatan US1000SP1 ultrascan camera (Gatan Inc.) was used for image capture, and the images were analyzed using Gatan 2.11 software.

Turbidity. Turbidity of rSM and pSM samples treated by alkalinization and UHPH and their respective controls were monitored using a Hach Model 2100AN IS turbidimeter (Hach Company). The instrument was calibrated using formazin primary standards (Hach Company), ranging between 20 and 7,500 nephelometric turbidity units. Samples $(30 \mathrm{~mL}$ ) of each solution were analyzed in a clean sample cell.

Protein Content. Analysis of the protein content in the supernatant of nonhomogenized and UHPH-treated rSM and pSM at the different $\mathrm{pH}$ was determined using the Bio-Rad DC Protein Assay kit (Bio-Rad) based on the well-known reaction of proteins with alkaline copper tartrate solution and Folin-Ciocalteu reagent (Lowry et al., 1951). Samples were diluted 5-fold before analysis and the absorbance read at $750 \mathrm{~nm}$ with an Agilent 8453 UV-visible spectrophotometer (Agilent Technologies Inc.). Bovine serum albumin (Bio-Rad) was used as a protein standard to generate a linear calibration curve with concentrations ranging from 0 to $2,000 \mu \mathrm{g} / \mathrm{mL}$. Two measures of the optical density were carried out for each sample.

Determination of Protein Distribution Between the Serum and Colloidal Phases. Protein profiles of control, UHPH-treated milk (rSM and pSM), and their respective supernatants were determined by SDS-PAGE under reducing conditions, using $12 \%$ polyacrylamide gels (TGX Stain-Free, Bio-Rad). Samples were diluted 6-fold with deionized water. Twenty microliters of diluted samples was combined with $1 \mu \mathrm{L}$ of $\beta$-mercaptoethanol and $19 \mu \mathrm{L}$ of $2 \times$ Laemmli buffer (Bio-Rad). Samples were then heated at $100^{\circ} \mathrm{C}$ for 5 min, and $15 \mu \mathrm{L}$ was loaded into the gel. Five microliters of molecular weight marker (Precision plus prestained, Bio-Rad) was loaded in the first well. Running buffer was prepared with $100 \mathrm{~mL}$ of $10 \times$ Tris-glycine SDS buffer (Bio-Rad) and $900 \mathrm{~mL}$ of deionized water. Electrophoresis was carried out at $15 \mathrm{~mA}$ per gel. Gels were stained for $60 \mathrm{~min}$ with a solution of Coomassie Brilliant Blue R-250 [10\% acetic acid, 40\% ethanol, and
$50 \%$ water ( $\mathrm{vol} / \mathrm{vol})]$ and unstained with a solution of $10 \%$ acetic acid, $10 \%$ methanol, and $80 \%$ water (vol/ vol). Images of the gel were captured with the ChemiDoc MP Imaging System (Bio-Rad).

\section{Statistical Analysis}

All experiments were carried out in triplicate. A factorial analysis carried out to assess the simple effects and interactions between $\mathrm{pH}$ value $(6.7,8.5$, and 10.5), UHPH level (0, 100, 200, and $300 \mathrm{MPa})$, and the pasteurization of milk (rSM or pSM) by ANOVA. Tukey's test was then carried out for multiple mean comparisons using Statistical Analysis System (SAS) University Edition, SAS Studio 3.5 software (SAS Institute Inc.). The analyses were carried out at a significance level of $P<0.05$.

\section{RESULTS}

\section{Effect of $\mathrm{pH}$ and UHPH on Milk Properties}

The effects of alkaline $\mathrm{pH}$ and UHPH on the PSD were monitored by laser diffraction for rSM and pSM. Figure 2 shows the results of the effect of UHPH pressures on the PSD of rSM and pSM at different $\mathrm{pH}$ values.

At $\mathrm{pH}$ 6.7, both nonhomogenized rSM and pSM controls (0 MPa) show similar PSD, characterized by the main population ranging from approximately 0.04 to about $1.0 \mu \mathrm{m}$ and a tiny population above $1.0 \mu \mathrm{m}$ (Figure $2 \mathrm{~A}$ ). When UHPH pressure was increased, a narrowing of the width of the principal peak was observed and the effect was more extreme on pSM than rSM (Table 2). Furthermore, the larger particles observed above $1 \mu \mathrm{m}$ in the PSD of both nonhomogenized SM samples disappeared as the pressure increased to 200 MPa.

The UHPH treatment also modified the SM PSD profiles at $\mathrm{pH} 8.5$ (Figure 2B). Contrary to $\mathrm{pH} 6.7$, UHPH did not affect the span index for the rSM, whereas UHPH treatments at $300 \mathrm{MPa}$ of pSM significantly $(P<0.001)$ decreased the span index values. In addition, increasing the $\mathrm{pH}$ from 6.7 to 8.5 resulted in significantly larger sized particles in the nonhomogenized rSM $(P=0.022)$ and pSM $(P=0.0169)$ compared with $\mathrm{pH} 6.7$ (Table 2). The particle size profiles for both nonhomogenized SM samples further increased as $\mathrm{pH}$ was adjusted to 10.5 (Figure 2C). However, after UHPH treatment, the size profiles shifted progressively back toward original values, indicating a strong pressure effect on the particle size at $\mathrm{pH}$ 10.5. However, a significant decrease in the span value was observed 

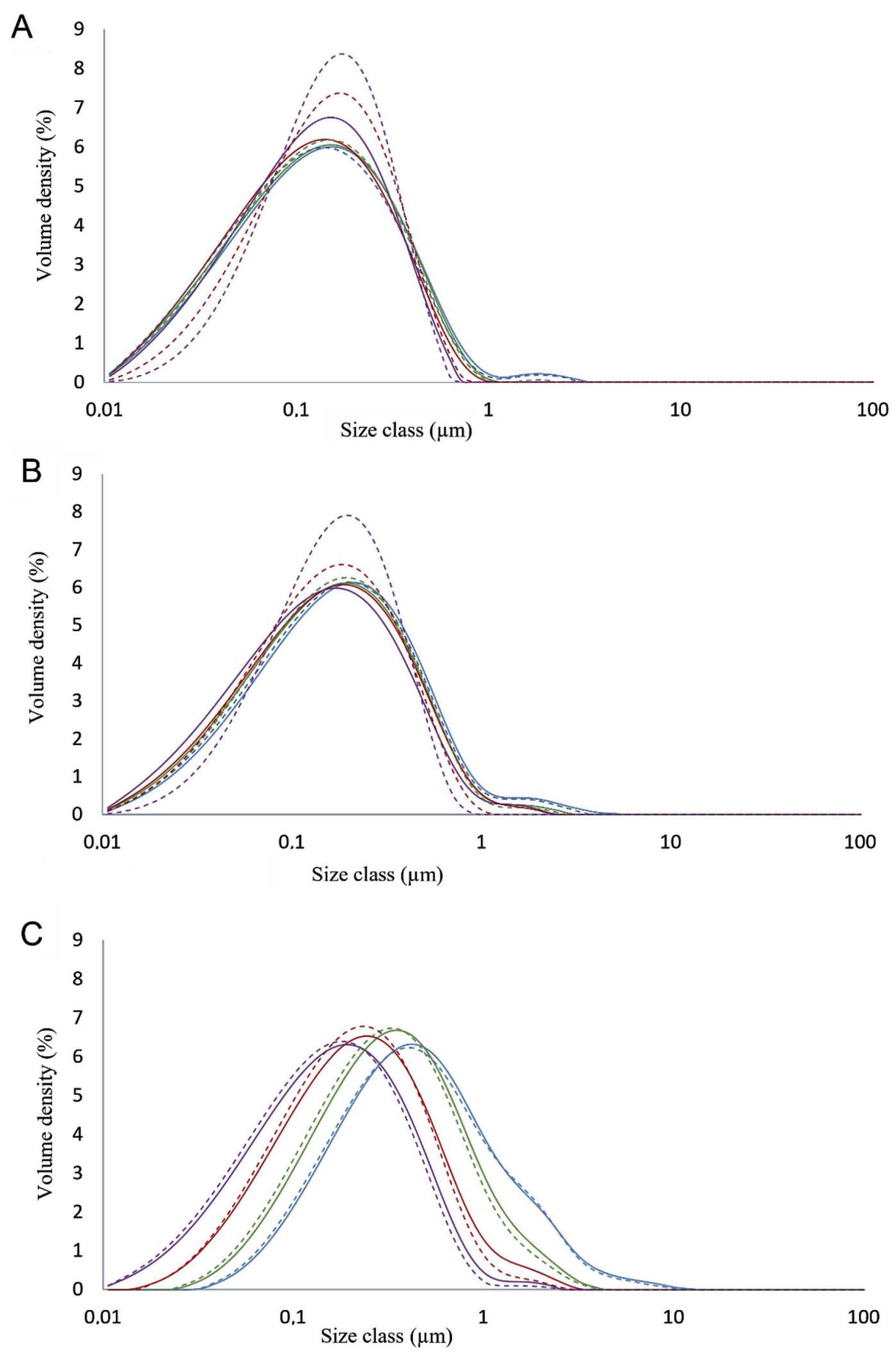

Figure 2. Particle size distribution for raw skim milk (rSM; plain line) and pasteurized skim milk (pSM; stippled line) at pH 6.7 (A), 8.5 (B), and 10.5 (C) for control (blue), $100 \mathrm{MPa}$ (green), $200 \mathrm{MPa}$ (red), and $300 \mathrm{MPa}$ (orange) samples. 
Table 2. Particle size parameters of raw (rSM) and pasteurized (pSM) skim milk ${ }^{1}$

\begin{tabular}{|c|c|c|c|c|c|c|c|}
\hline $\begin{array}{l}\mathrm{pH} \\
\text { value }\end{array}$ & $\begin{array}{l}\text { Pressure } \\
(\mathrm{MPa})\end{array}$ & \multicolumn{2}{|c|}{$\mathrm{D}_{4,3}^{2}(\mathrm{~nm})$} & \multicolumn{2}{|c|}{$\mathrm{D}_{3,2}^{3}(\mathrm{~nm})$} & \multicolumn{2}{|c|}{ Span } \\
\hline \multirow[t]{3}{*}{6.7} & 0 & $196.3 \pm 32.2^{\mathrm{a}}$ & $183.0 \pm 13.2^{\mathrm{a}}$ & $79.0 \pm 7.7^{\mathrm{ab}}$ & $73.6 \pm 1.7^{\mathrm{a}}$ & $2.89 \pm 0.11^{\mathrm{bc}}$ & $2.93 \pm 0.20^{\mathrm{c}}$ \\
\hline & 200 & $160.0 \pm 5.0^{\mathrm{a}}$ & $172.0 \pm 8.7^{\mathrm{a}}$ & $73.1 \pm 1.1^{\mathrm{a}}$ & $93.0 \pm 11.7^{\mathrm{ab}}$ & $2.75 \pm 0.08^{\mathrm{ab}}$ & $2.22 \pm 0.24^{\mathrm{ab}}$ \\
\hline & 300 & $155.7 \pm 16.9^{\mathrm{a}}$ & $172.3 \pm 4.7^{\mathrm{a}}$ & $79.9 \pm 19.1^{\mathrm{ab}}$ & $104.3 \pm 3.1^{\mathrm{c}}$ & $2.48 \pm 0.39^{\mathrm{a}}$ & $1.91 \pm 0.02^{\mathrm{a}}$ \\
\hline 8.5 & 0 & $280.3 \pm 28.6^{\mathrm{bc}}$ & $259.0 \pm 33.8^{\mathrm{bc}}$ & $104.7 \pm 14.2^{\mathrm{bc}}$ & $100.4 \pm 13.6^{\mathrm{c}}$ & $2.93 \pm 0.12^{\mathrm{bc}}$ & $2.88 \pm 0.08^{\mathrm{c}}$ \\
\hline \multirow[t]{4}{*}{10.5} & 0 & $734.0 \pm 151.2^{\mathrm{e}}$ & $701.0 \pm 154.4^{\mathrm{e}}$ & $291.7 \pm 37.3^{\mathrm{f}}$ & $280.3 \pm 33.2^{\mathrm{f}}$ & $3.19 \pm 0.63^{\mathrm{c}}$ & $3.35 \pm 0.58^{\mathrm{d}}$ \\
\hline & 100 & $469.3 \pm 55.8^{\mathrm{d}}$ & $433.7 \pm 35.4^{\mathrm{d}}$ & $217.0 \pm 13.1^{\mathrm{e}}$ & $202.7 \pm 3.8^{\mathrm{e}}$ & $2.80 \pm 0.24^{\mathrm{ab}}$ & $2.74 \pm 0.28^{\mathrm{c}}$ \\
\hline & 200 & $322.3 \pm 21.2^{\mathrm{c}}$ & $277.7 \pm 16.7^{\mathrm{c}}$ & $141.7 \pm 4.9^{\mathrm{d}}$ & $135.0 \pm 1.7^{\mathrm{d}}$ & $2.82 \pm 0.26^{\mathrm{ab}}$ & $2.53 \pm 0.12^{\mathrm{bc}}$ \\
\hline & 300 & $226.7 \pm 3.2^{\mathrm{ab}}$ & $210.7 \pm 13.3^{\mathrm{bc}}$ & $97.4 \pm 2.9^{\mathrm{bc}}$ & $93.8 \pm 3.7^{\mathrm{ab}}$ & $2.74 \pm 0.05^{\mathrm{ab}}$ & $2.67 \pm 0.09^{\mathrm{bc}}$ \\
\hline
\end{tabular}

\footnotetext{
${ }^{\mathrm{a}-\mathrm{f}}$ Mean values in the same column with different superscript lowercase letters are significantly different $(P<0.05)$.

${ }^{1}$ Means $\pm \mathrm{SD}(\mathrm{n}=3)$.

${ }^{2} \mathrm{D}_{4,3}$ : volume-weighted mean diameter.

${ }^{3} \mathrm{D}_{3,2}$ : surface-weighted mean diameter.
}

for rSM and pSM for all the various levels of pressure tested using UHPH at $\mathrm{pH} 10.5$.

Figure 3 presents TEM images of rSM and pSM at 0 and $300 \mathrm{MPa}$ showing typical milk microstructure obtained at the different $\mathrm{pH}$. At $\mathrm{pH} 6.7$, although the presence of dense and compact micellar structures of different sizes was observed, no significant changes were detected after UHPH at $300 \mathrm{MPa}$ for rSM and pSM. After alkalinization at $\mathrm{pH} 8.5$ and 10.5 , the presence of larger CN structures was noted. However, these larger aggregated $\mathrm{CN}$ forms were disrupted when treated at $300 \mathrm{MPa}$, resulting in smaller CN particles.

The effects of alkaline $\mathrm{pH}$ and UHPH treatments on the particle size parameters of rSM and pSM are shown in Table 2. Statistical analysis revealed a significant effect of the interaction between $\mathrm{pH}$ and pressure $(P<$ $0.0001)$ for the volume-weighted mean diameter $\left(\mathrm{D}_{4,3}\right.$; Supplemental Figure S1; https://doi.org/10.17632/ g6zj5dfrm3.2; Brisson, 2022). While alkalinization of the nonhomogenized samples induced a significant increase of the $\mathrm{D}_{4,3}$, the effect of UHPH treatment differs from one $\mathrm{pH}$ to the other. A more significant reduction of the particle size was observed at $\mathrm{pH} 10.5$ compared with $\mathrm{pH} 8.5$ and 6.7 . The $\mathrm{D}_{4,3}$ decreased very significantly $(P<0.001)$ for rSM and pSM while increasing the pressure from 0 to $300 \mathrm{MPa}$.

Statistical analysis revealed a highly significant interaction between $\mathrm{pH}$ and pressure $(P<0.0001)$ and a significant effect on the pasteurization treatment and pressure $(P=0.0487)$ of the surface-weighted mean diameter $\left(\mathrm{D}_{3,2} ;\right.$ Supplemental Figure $\left.\mathrm{S} 1\right)$. Whereas no effect of UHPH on the $\mathrm{D}_{4.3}$ was observed at $\mathrm{pH} 6.7$ for both SM types, a significant reduction of the $\mathrm{D}_{3,2}$ of the $\mathrm{CN}$ micelles was noted for the pSM treated at $300 \mathrm{MPa}$. In contrast, the UHPH treatment did not affect the $\mathrm{D}_{3,2}$ for $\mathrm{rSM}$ at $\mathrm{pH}$ 6.7. However, only the pSM samples were affected by the UHPH at $\mathrm{pH}$ 8.5. Furthermore, maximal $\mathrm{D}_{3,2}$ values were reached at $\mathrm{pH}$ 10.5 for control rSM and pSM. However, as the UHPH pressure increased, a significant decrease of $\mathrm{D}_{3,2}$ was noted for both SM types.

\section{Effect of Treatments on Turbidity}

The turbidity of protein solutions was used to assess their level of aggregation, particle density, and solubility. The turbidity of SM samples was measured as a function of $\mathrm{pH}$ and UHPH treatment, as shown in Figure 4. For the most part, the turbidity of rSM and pSM decreased drastically as the $\mathrm{pH}$ increased from 6.7 to $\mathrm{pH}$ 10.5. As the UHPH pressure was increased, the turbidity of $\mathrm{rSM}$ at $\mathrm{pH} 6.7$ and 8.5 decreased slightly but remained constant at $\mathrm{pH}$ 10.5. Likewise, the turbidity of $\mathrm{pSM}$ at $\mathrm{pH} 6.7$ also decreased as the UHPH pressure increased; however, at alkaline $\mathrm{pH}$ UHPH had no effect. A significant triple interaction was observed between pasteurization treatment, $\mathrm{pH}$, and pressure $(P$ $=0.0130)$ on the turbidity values. For example, the turbidity of nonhomogenized $\mathrm{rSM}(0 \mathrm{MPa})$ samples decreased as the $\mathrm{pH}$ increased. Over the same range of $\mathrm{pH}$, lower turbidity values were recorded for pSM. Comparable results were observed at $100 \mathrm{MPa}$, except for $\mathrm{rSM}$ at $\mathrm{pH}$ 8.5, which showed significantly lower turbidity than at $0 \mathrm{MPa}$. At 200 and $300 \mathrm{MPa}$, the effect of pasteurization was only seen for $\mathrm{pH} 6.7$ and 8.5. A similar result was noted at $\mathrm{pH} 8.5$ and $200 \mathrm{MPa}$, 
with a significant difference $(P=0.0259)$ between $\mathrm{rSM}$ and pSM. Finally, at $300 \mathrm{MPa}$, the turbidity decreased, but no significant differences were seen between $\mathrm{pH} 8.5$ and 10.5 .

\section{Effect of $\mathrm{pH}$ and UHPH on Protein Distribution}

To understand the effect of alkaline $\mathrm{pH}$ and UHPH on the protein distribution within the serum and col-
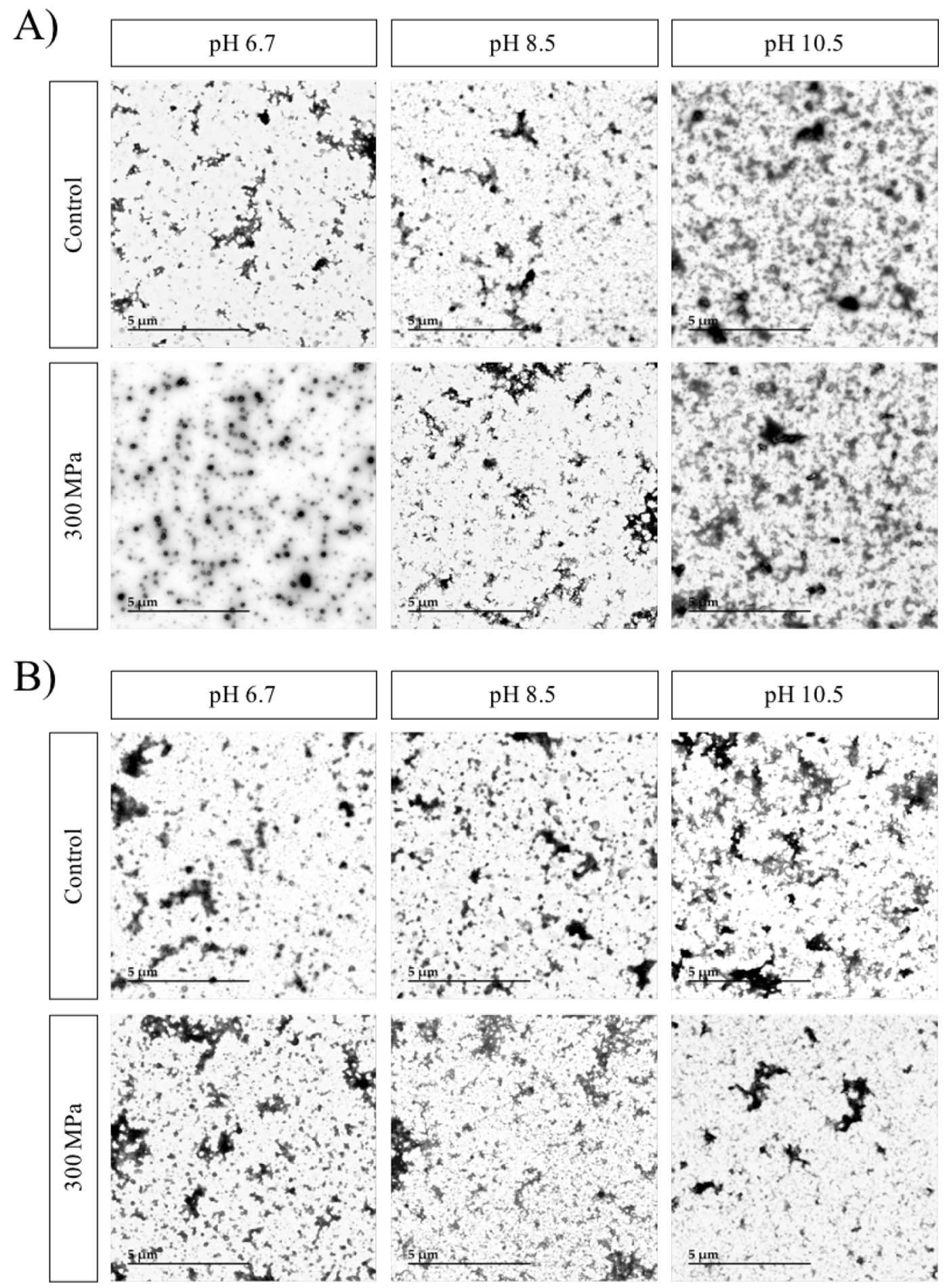

Figure 3. Microstructure images of raw skim milk (rSM; A) and pasteurized skim milk (pSM; B) for control and $300 \mathrm{MPa}$ samples at different $\mathrm{pH}$ values observed by transmission electron microscopy at $4 \mathrm{~K}$. 


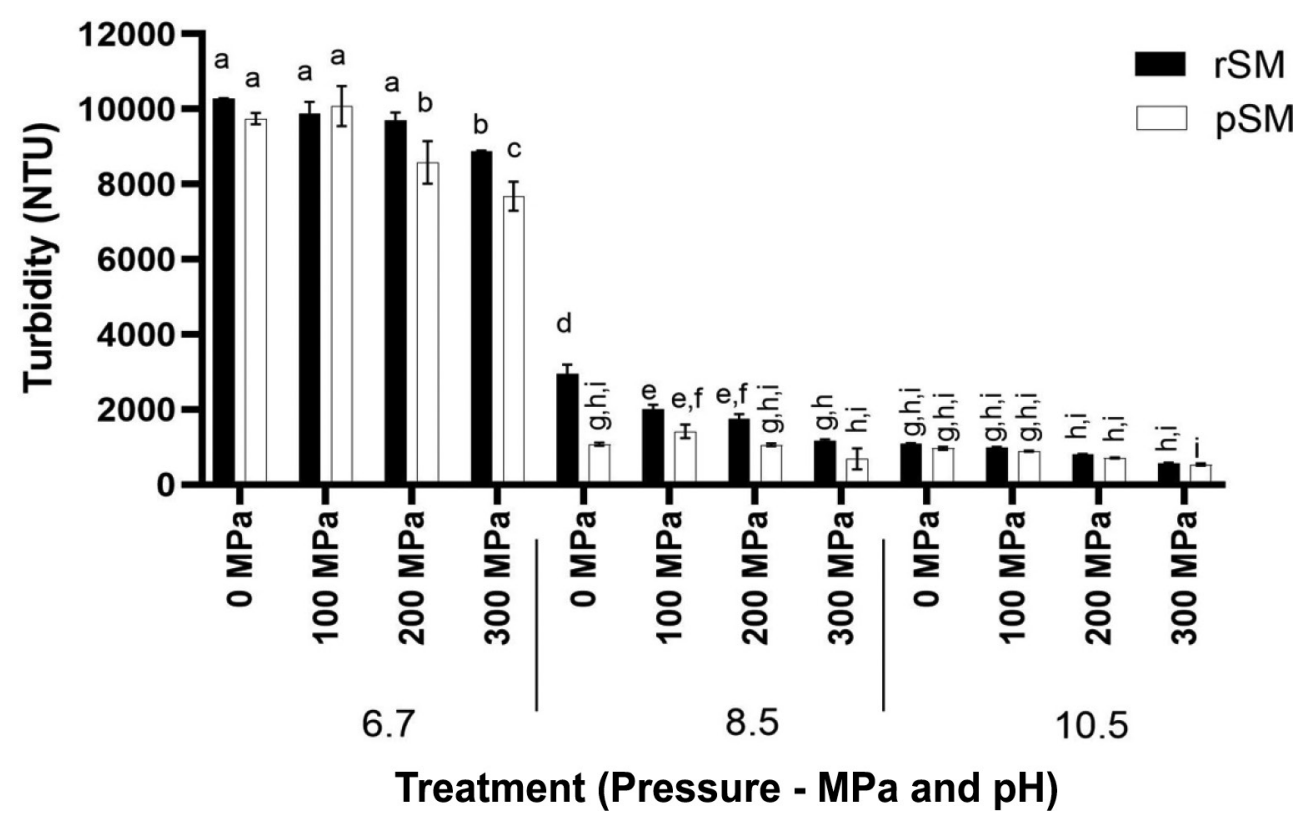

Figure 4. Turbidity of raw skim milk (rSM; black bars) and pasteurized skim milk (pSM; white bars), at pH 6.7, 8.5, and 10.5 for control, 100, 200, and 300 MPa. Bars represent mean values of triplicates, and error bars indicate SD for each treatment. NTU = nephelometric turbidity unit.

loidal phase, the treated rSM and pSM were fractionated by ultracentrifugation, as described above, and we measured the protein content of each serum fraction (supernatant). Figure 5 shows SDS-PAGE analysis of the repartition of milk proteins in the control and pressure-treated rSM and pSM following ultracentrifugation in the serum fraction at different $\mathrm{pH}$ values. The SDS-PAGE analysis shows differences in the partition of the $\mathrm{CN}$ after ultracentrifugation. The distribution of $\mathrm{CN}$ in the supernatants varied according to the $\mathrm{pH}$ and UHPH treatments and the pasteurization. For rSM at $\mathrm{pH} 6.7$ (Figure 5A), only small amounts of the 3 types of $\mathrm{CN}\left(\alpha_{\mathrm{s}}-\mathrm{CN}, \beta-\mathrm{CN}\right.$, and $\left.\kappa-\mathrm{CN}\right)$ were recovered in the serum phase, independent of the UHPH pressure. In contrast, very faint $\mathrm{CN}$ bands were observed in the supernatant for the UHPH-treated pSM samples, compared with the nonhomogenized control, with $\beta$-CN and $\kappa$-CN almost undetectable for the UHPH samples. However, these slight modification in $\mathrm{CN}$ distribution at initial $\mathrm{pH}$ between the colloidal and serum phases were not significant based on protein content, as shown in Figure 6 (for both rSM and pSM at $\mathrm{pH}$ 6.7). In comparison, at $\mathrm{pH} 8.5$ as the UHPH pressure was increased (Figure 5B and $5 \mathrm{E}$ ), $\alpha_{\mathrm{S}^{-}} \mathrm{CN}, \beta-\mathrm{CN}$, and $\kappa-\mathrm{CN}$ band intensity in the supernatant increased, which correlated with a significant increase in total protein concentration in rSM and pSM supernatants. Last, the $\mathrm{pH}$ adjustment of pSM resulted in a significant increase of protein content into the serum fractions (Figure 6), especially at $\mathrm{pH}$ 10.5. However, no effect was observed on those samples after using UHPH treatment.

\section{DISCUSSION}

This study investigated the effect of alkalinization and UHPH treatment of SM on the integrity and size of $\mathrm{CN}$ micelles. Both rSM and pSM were tested to see the influence of pasteurization treatment on the sensitivity of $\mathrm{CN}$ micelles to alkalization and $\mathrm{UHPH}$ treatments. The results show the alkaline $\mathrm{pH}$ and UHPH pressure have a significant influence on the structure of the CN micelles and their repartition between the serum and colloidal phases, which could have an extensive effect on their functionality during dairy processing.

\section{Effect of $\mathrm{pH}$ and UHPH on PSD and Parameters}

At the initial $\mathrm{pH}$ of $\mathrm{SM}$ (6.7), 2 populations were observed. These results agreed with the literature on SM PSD. Zamora et al. (2007) also reported a principal population at $0.2 \mu \mathrm{m}$, corresponding to $\mathrm{CN}$ micelles, and a minor one around $3.8 \mu \mathrm{m}$ corresponding to remaining fat globules that could not be separated with the cream separator. In addition, because $\mathrm{CN}$ micelles are the most abundant colloidal particles in SM, any modifications of the particle size parameters can be associated with change in conformation and structure of the micelle (Fox and Brodkorb, 2008; Chen et al., 
2019). At pH 6.7, we observed a very slight decrease in the volume-weighted mean diameter $\left(\mathrm{D}_{4.3}\right)$ after $\mathrm{UHPH}$ treatment, which agreed with the results obtained by Hayes and Kelly (2003) and Lodaite et al. (2009), who reported a $\mathrm{CN}$ micelle size reduction of about $5 \%$ in the UHPH range ( $>200 \mathrm{MPa})$. In contrast, a larger size reduction has been observed, up to $33 \%$, for phosphocasein dispersion (Chevalier-Lucia et al., 2011). Hayes and Kelly (2003) observed a decrease in the particle size of pSM, from $183.5 \mathrm{~nm}(0 \mathrm{MPa})$ to $160.2 \mathrm{~nm}(300$ $\mathrm{MPa}$ ). This study obtained a comparable but insignificant decrease from 196.3 and $155.7 \mathrm{~nm}$ for pSM using similar UHPH pressure. This slight decrease in the particle size parameters may be due to a partial dissociation of the CN micelle surface, and the size reduction of the remaining milk fat globules under UHPH (Sandra and Dalgleish, 2005). The absence of the larger population observed for higher pressure (Figure 2A) has been attributed to the disruption of the milk fat globules into submicronic and more homogeneous fat globules (Zamora et al., 2012). It resulted in the sharpening of the principal peak associated with the $\mathrm{CN}$ micelles (Figure 2), as a function of pressure, that correlated with a decrease of span values which reflect higher homogeneity of the CN micelle size distribution (Tan and Nakajima, 2005). At initial $\mathrm{pH}$ (6.7), the majority $(95 \%)$ of the $\mathrm{CN}$ is incorporated into micellar form sta- bilized by CCP (Chen et al., 2019; Zouari et al., 2020). Various molecular forces are essential to maintain the structure and stability of $\mathrm{CN}$ micelles, which depend on a balance between electrostatic repulsions and hydrophobic interactions. In addition, CCP crosslinks the CN molecules and neutralizes the negatively charged phosphoseryl groups, allowing hydrophobic interactions between CN (Broyard and Gaucheron, 2015). Thus, the slight decrease in particle size observed after UHPH could be related to the disruption of hydrophobic and ionic interactions throughout the high pressure, cavitation, turbulence, and shear effects (Bouaouina et al., 2006). Furthermore, it has been reported that in raw milk, $\kappa-\mathrm{CN}$, and to a lesser extent $\alpha_{\mathrm{S}}-\mathrm{CN}$, present on the surface of the native CN micelle are readily affected by UHPH and get partially solubilized, resulting in a decrease in the CN micelle size (Sandra and Dalgleish, 2005; Regnault et al., 2006). However, as observed by SDS-PAGE, we did not detect the solubilization of either $\kappa-\mathrm{CN}$ and $\alpha_{\mathrm{s}} \mathrm{CN}$ after UHPH. Instead, whereas no dissolution was observed in rSM, a decrease in nonsedimentable $\mathrm{CN}$ recovered in the serum phase was noted for pSM after ultracentrifugation. The exact reasons for our discrepancies with those authors are not known.

In addition, an increase in span values was observed as the $\mathrm{pH}$ increased, particularly at $\mathrm{pH}$ 10.5. The results clearly showed that $\mathrm{CN}$ micelles are highly af-
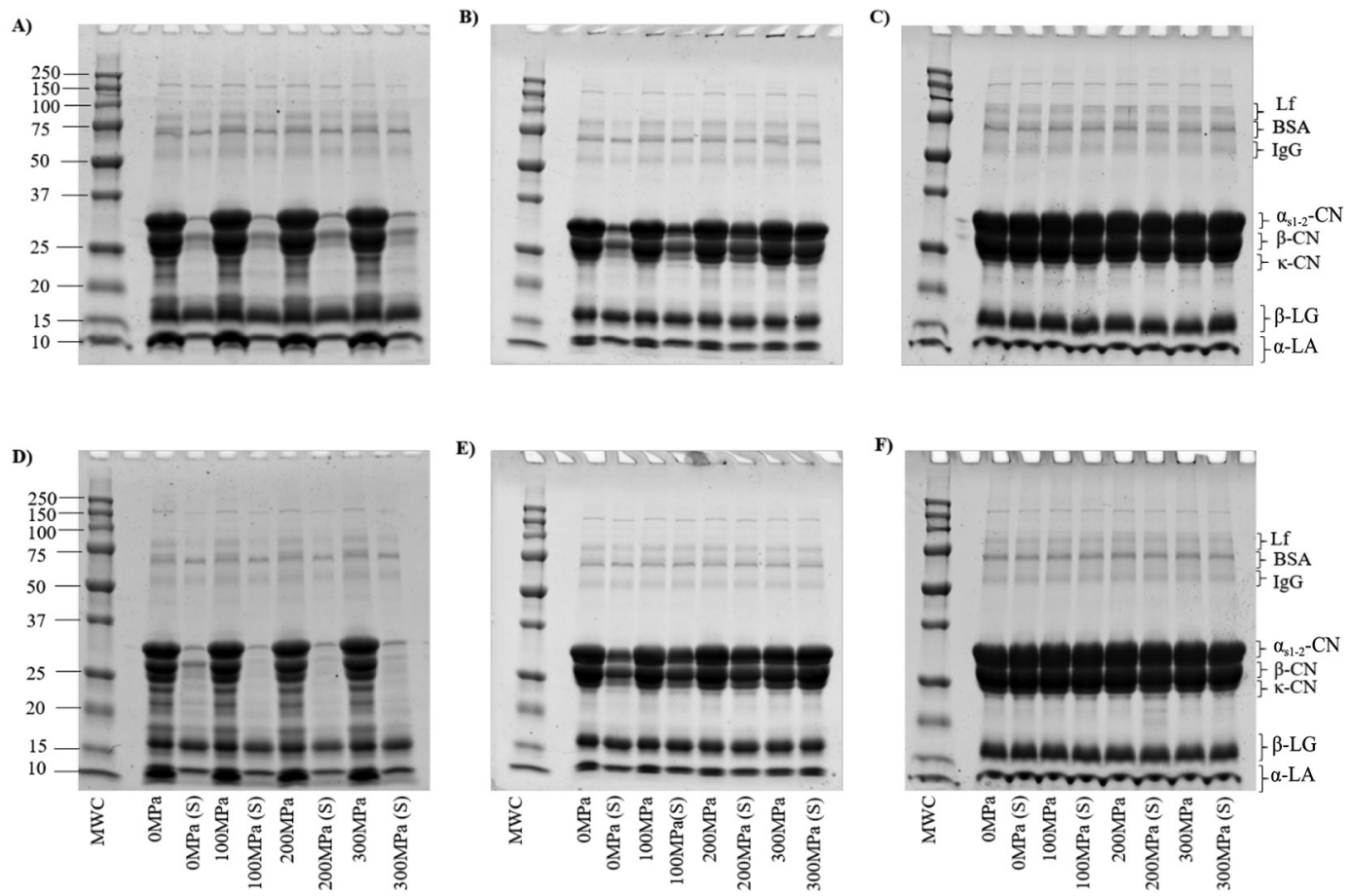

Figure 5. SDS-PAGE profile of control and ultra-high-pressure homogenization (UHPH)-treated raw milk (A, B, and C) and pasteurized milk $(\mathrm{D}, \mathrm{E}$, and $\mathrm{F})$ at $\mathrm{pH} 6.7(\mathrm{~A}$ and $\mathrm{D}), 8.5(\mathrm{~B}$ and $\mathrm{E})$, and $10.5(\mathrm{C}$ and $\mathrm{F})$ and their respective supernatant $(\mathrm{S})$ recovered after ultracentrifugation at $70,000 \times g$ for $1 \mathrm{~h}$ at $20^{\circ} \mathrm{C}$. MWC $=$ molecular weight control $(\mathrm{kDa})$. $\mathrm{Lf}=$ lactoferrin. 
fected by the alkaline $\mathrm{pH}$ and show an increase in the heterogeneity of the CN particle size. Madadlou et al. (2009b) stated that alkalinization at a $\mathrm{pH}$ up to 12.0 induces the individual caseins to gain negative charges, thus increasing the net global negative charge. They attribute this phenomenon to complete deprotonation of the carboxyl groups, combined with a loss of positive charge on the histidine and lysine residues and an increase of the negative charges on the phosphoseryl residues. Their deprotonation converted them from single to double negatively charged units, leading to strong electrostatic repulsions (Post et al., 2012). These reactions may have contributed to the distancing of the individual $\mathrm{CN}$ polypeptide chains from one another, resulting in a looser and more expanded $\mathrm{CN}$ micelle structure. Nevertheless, the attractive electrostatic forces and hydrophobic interactions within the CN micelles could still be sufficient to maintain the micellar cohesion and as such play an essential role in their self-assembly at higher $\mathrm{pH}$. According to Liu and Guo (2008), the hydroxyl ions, introduced by $\mathrm{NaOH}$ addition, increase the electrical conductivity and thus the number of hydrogen bonds between serum and colloidal phases, likely causing breakage of some hydrogen and hydrophobic bonds between the $\mathrm{CN}$ polypeptidic chains and eventually weakening the micelle structure (Liu and Guo, 2008). Moreover, hydrophobic interactions among the $\mathrm{CN}$ have been shown to have little dependence on $\mathrm{pH}$, suggesting that electrostatic inter- actions play an essential role in the $\mathrm{pH}$-dependent behavior of CN micelles (Anema, 1998). Contrary to our observations, Vaia et al. (2006) and Sinaga et al. (2017) found that $\mathrm{CN}$ micelles were disrupted at alkaline $\mathrm{pH}$ between $\mathrm{pH} 8.0$ to 11.0. These authors suggested that the CN micelle disintegration was due to reduced cohesive interactions between the hydrophobic areas on the different CN. They also proposed that decreased ionic calcium and phosphate concentrations increase the serum phase's solvent quality, which maintains the cohesive interactions. Furthermore, the presence of attractive and repulsive interactions between the proteins may lead to CN dissociation (Vaia et al., 2006; Sinaga et al., 2017). However, Ahmad et al. (2009) showed that these solubilized dissociated $\mathrm{CN}$ molecules reorganized into soluble aggregates of increasing sizes, which agrees with our laser diffraction observations.

Although more studies are still needed to decipher the exact mechanisms that $\mathrm{CN}$ micelles undergo during alkalinization, our TEM images clearly showed the presence of numerous micron size particles at $\mathrm{pH} 10.5$, which provides further evidence of the formation of larger self-associating $\mathrm{CN}$ forms at alkaline $\mathrm{pH}$.

Our results also showed a significant interaction between $\mathrm{pH}$ and UHPH pressure on the reduction of $\mathrm{CN}$ micelle size. The $\mathrm{CN}$ micelle structure is thought to be weakened at higher $\mathrm{pH}$ values, which is likely only supported by hydrophobic interactions. In this loosened state, the casein micelles are likely more prone to

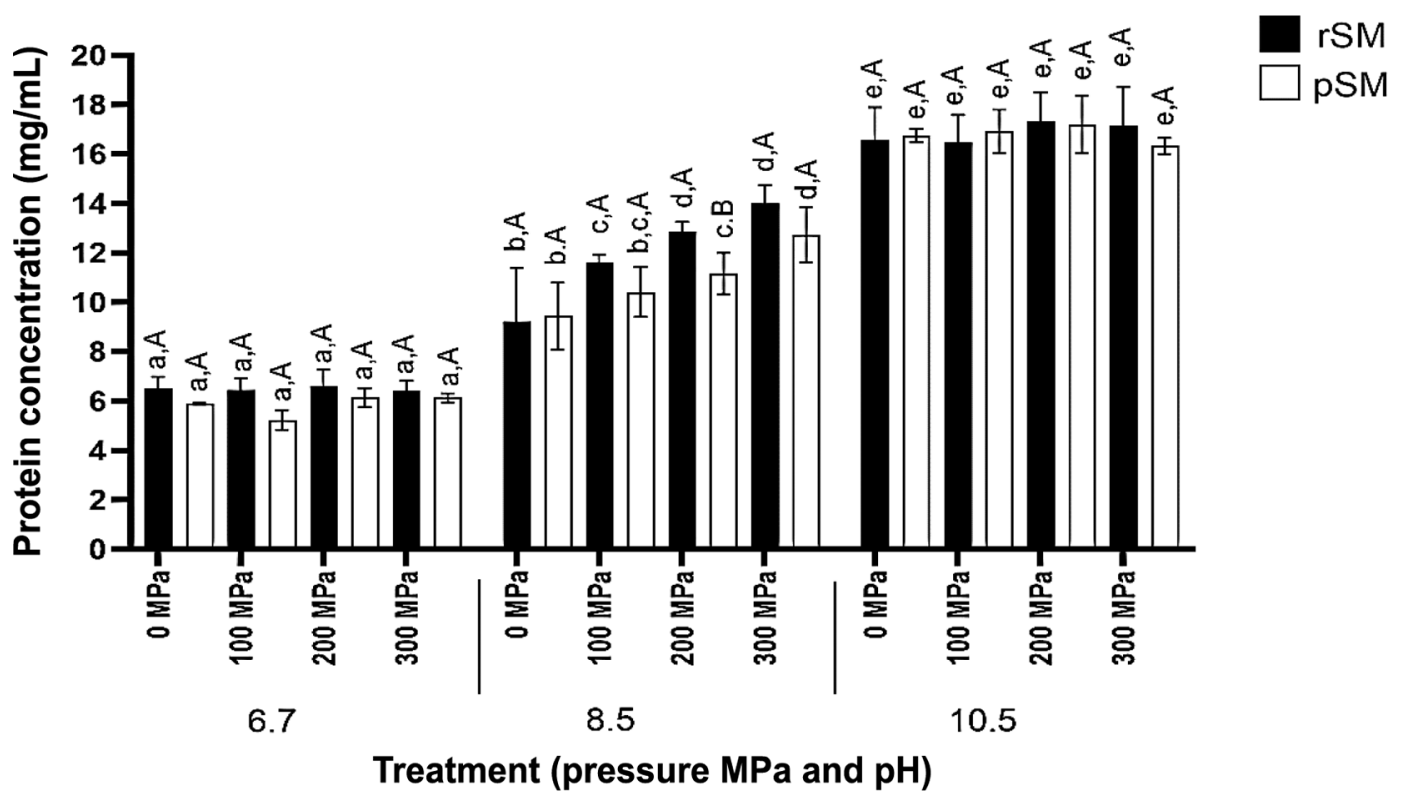

Figure 6. Protein content $(\mathrm{mg} / \mathrm{mL})$ in milk supernatants as a function of ultra-high-pressure homogenization (UHPH), pH, and pasteurization treatment. Bars represent mean values of triplicates, and error bars indicate SD for each treatment. $\mathrm{rSM}=\mathrm{raw}$ skim milk; pSM $=$ pasteurized skim milk. Bars with lowercase letters $(\mathrm{a}-\mathrm{e})$ are significantly different $(P<0.05)$ within the same pasteurization treatment. Bars with uppercase letters $(\mathrm{A}, \mathrm{B})$ are significantly different $(P<0.05)$ within the same $\mathrm{pH} \times$ pressure treatments. 
disruption by UHPH. Similar to our study, Madadlou et al. (2009a) also reported that sonication induced a global particle size reduction of loosened and fragilized $\mathrm{CN}$ micelles at alkaline $\mathrm{pH}$, through cavitating forces, which could act similarly to the cavitating forces generated by UHPH.

\section{Effect of $\mathrm{pH}$ and UHPH on Casein Micelle Structure and Protein Distribution Between the Serum and Colloidal Phase}

Turbidity measurements and gel electrophoresis profiles to assess the effect of $\mathrm{pH}$ and UHPH on protein structure and distribution were assessed after the partition of SM serum and colloidal micellar phases through ultracentrifugation. As previously mentioned, turbidity depends on the particle's size, concentration, and light-scattering properties. In SM, CN micelles are the primary light-scattering particles, and changes in their turbidity will reflect mainly structural modifications to the micelles (Madadlou et al., 2009b). For the most part, our results showed a significant decrease in the turbidity of rSM and pSM as $\mathrm{pH}$ increased from 6.7 to $\mathrm{pH}$ 10.5. Changes in turbidity with UHPH treatment depended on the pasteurization of $\mathrm{SM}$ and $\mathrm{pH}$. For example, UHPH treatment reduced the turbidity for $\mathrm{rSM}$ at $\mathrm{pH} 6.7$ and 8.5 and for pSM at $\mathrm{pH} 6.7$ only. At $\mathrm{pH}$ 6.7, the significant decrease of rSM turbidity at 200 and $300 \mathrm{MPa}$ may be due to partial disintegration of the CN micelle surface and possible collapse of the protruding $\mathrm{k}-\mathrm{CN}$ glycosylated part on the surface of the $\mathrm{CN}$ micelles. At that $\mathrm{pH}$, the $\mathrm{CN}$ micelles are at their most compact structure, leading to the highest scattering factor of particle, hence higher turbidity. On the other hand, at higher $\mathrm{pH}$ values, the self-aggregating loose and expanded CN structures probably contain more voids than their micellar more compact arrangement, which may reduce the light beam scattering and the associated measured turbidity. Moreover, the CN size increase is concomitant with a smaller specific surface area available for light scattering, leading to a decrease in the observed turbidity of CN solutions with increasing $\mathrm{pH}$ in the alkaline range (Liu and Guo, 2008; Madadlou et al., 2009b).

The analysis of the distribution of proteins within the serum and colloidal fractions of SM was carried out by SDS-PAGE. The results showed only some slight effect of UHPH and $\mathrm{pH}$ treatments on $\mathrm{rSM}$ and $\mathrm{pSM}$ samples. As expected, for both control SM ( $\mathrm{pH}$ 6.7, $0 \mathrm{MPa}$ ), ultracentrifugation induced the sedimentation of $\mathrm{CN}$ micelles within the pellet (colloidal fraction), whereas the supernatant (serum fraction) was mainly composed of the WP such as $\beta$-LG (15 kDa) and $\alpha$-LA (14 kDa; Ahmad et al., 2009; Anema et al., 2014). However, gel electrophoresis showed a slight loss of $\beta-\mathrm{LG}$ and $\alpha$-LA for pSM into the colloidal fraction regardless of the pressure applied. $\beta$-LG, and to a lesser extent $\alpha-\mathrm{LA}$, are well known to undergo thermal denaturation and aggregation in the serum phase before associating with $\kappa-\mathrm{CN}$ at the surface of the micelles via intermolecular disulfide interactions during thermal treatment (Corredig and Dalgleish, 1996, 1999; Anema and Li, 2003). As $\beta-\mathrm{LG}$ and $\alpha$-LA sedimented with the $\mathrm{CN}$ micelles in the pellet, a lesser number of proteins were observed in the supernatant for pSM compared with rSM. However, as reported by Rynne et al. (2004), the extent of WP denaturation is relatively low (less than $3 \%$ ) for HTST pasteurized milk at $72^{\circ} \mathrm{C}$, and this would explain the relatively low WP loss in the CN micelles for the pSM, which was insignificant in terms of total protein loss. On the other hand, following alkalinization of both SM, SDS-PAGE analysis showed a partial recovery of nonsedimentable $\mathrm{CN}$ species in the supernatant at $\mathrm{pH}$ 8.5, whereas a complete recovery was observed at $\mathrm{pH}$ 10.5. The results were expected and in concordance with the observations of Ahmad et al. (2009) These authors suggest that the dissociation of the CN micelles in the alkaline $\mathrm{pH}$ range led to their reorganization into highly hydrated CN particles of various sizes, which can be seen in the increase in average size $\left(D_{4,3}\right.$ and $\left.\mathrm{D}_{3,2}\right)$ and span values, but also in our TEM images (Figure 3; Ahmad et al., 2009). Moreover, as the CN were no longer sedimentable after ultracentrifugation, the loss of WP observed at pH 6.7 for pSM was reverted entirely. All the WP were recuperated in the serum, confirming their association with the CN during pasteurization as mentioned above. However, we observed for the first time that the $\mathrm{CN}$ distribution between the serum and colloidal fraction was dependent on both $\mathrm{pH}$ and UHPH as the protein content in the serum phase increased sharply (Figure 6) with the UHPH pressure, suggesting a strong synergistic effect. Adjusting the $\mathrm{pH}$ of SM at alkaline $\mathrm{pH}$ induces a significant increase in the protein content in the serum phase, attributable to the solubilization of all the $\mathrm{CN}$ species as observed by SDS-PAGE.

Overall, the use of UHPH on SM adjusted at alkaline $\mathrm{pH}$ affects the protein concentration differently in the serum phases, attributed principally to nonsedimentable CN (Zouari et al., 2020). Intense CN bands were observed in the SDS-PAGE supernatant of SM control samples at higher $\mathrm{pH}$ values, especially at $\mathrm{pH}$ 10.5. It has been proposed that $\mathrm{CN}$ micelles progressively start swelling at alkaline $\mathrm{pH}$, inducing their dissociation followed by their reorganization into smaller highly hydrated particles and aggregates (Ahmad et al., 2009). The lower density of these more hydrated CN molecular forms prevents them from sedimenting in the pellet 
after ultracentrifugation (Ahmad et al., 2009). The lack of effect observed for UHPH-treated samples at $\mathrm{pH} 10.5$ showed that such drastic alkalinization itself is enough to disperse all $\mathrm{CN}$ into the serum phase. However, we showed that complete disruption of the $\mathrm{CN}$ micelle could be obtained at lower $\mathrm{pH}$ (8.5) when combined with UHPH treatment (200 and $300 \mathrm{MPa})$.

\section{CONCLUSIONS}

This study investigated the effect of alkalinization and UHPH treatment on CN micelle structural and organizational state in rSM and pSM. The important disruption of $\mathrm{CN}$ micelles in SM by a combination of $\mathrm{pH}$ and UHPH is seen here for the first time. Our results showed that alkalinization induces higher $\mathrm{CN}$ particle size throughout micelle swelling and their rearrangement into different increasing size forms, whereas UHPH treatment helps dissociate these fragile loose CN structures. As a result, complete redispersion of the $\mathrm{CN}$ micelles could be achieved at lower alkaline $\mathrm{pH}$ by using a UHPH treatment. Overall, this study showed the strong potential of using alkalinization and UHPH to change the CN micelle structure synergistically, and modify their techno-functional properties and behavior when incorporated in dairy products.

\section{ACKNOWLEDGMENTS}

The authors thank Diane Gagnon and Pascal Lavoie (Food Science Department, Université Laval, Quebec, Canada) for technical support. The authors also thank Richard Janvier [Institute for Integrative Systems Biology (IBIS), Université Laval] for technical support and assistance with TEM. We also acknowledge the Natural Sciences and Engineering Research Council of Canada (NSERC, Ottawa, Canada; grant number CRDPJ/537396-2018), the Quebec consortium for industrial bioprocess research and innovation (CRIBIQ, Quebec, Canada), and Novalait Inc. (Quebec, Canada) for the financial support of this project. Serine Touhami was supported by a master's degree scholarship from the Canadian Dairy Commission (Ottawa, Canada). The authors are grateful to David M. F. Thomas (DMFT Translation, Quebec, Canada) for editing this manuscript. The authors have not stated any conflicts of interest.

\section{REFERENCES}

Ahmad, S., M. Piot, F. Rousseau, J. F. Grongnet, and F. Gaucheron. 2009. Physico-chemical changes in casein micelles of buffalo and cow milks as a function of alkalinisation. Dairy Sci. Technol. 89:387-403. https://doi.org/10.1051/dst/2009020.
Alexander, M., L. F. Rojas-Ochoa, M. Leser, and P. Schurtenberger. 2002. Structure, dynamics, and optical properties of concentrated milk suspensions: An analogy to hard-sphere liquids. J. Colloid Interface Sci. 253:35-46. https://doi.org/10.1006/jcis.2002.8452.

Anema, S. G. 1998. Effect of milk concentration on heat-induced, pHdependent dissociation of casein from micelles in reconstituted skim milk at temperatures between 20 and 120 degrees C. J. Agric. Food Chem. 46:2299-2305. https://doi.org/10.1021/jf970909+.

Anema, S. G., and Y. M. Li. 2003. Association of denatured whey proteins with casein micelles in heated reconstituted skim milk and its effect on casein micelle size. J. Dairy Res. 70:73-83. https://doi .org/10.1017/S0022029902005903.

Anema, S. G., E. K. Lowe, S. K. Lee, and H. Klostermeyer. 2014 Effect of the $\mathrm{pH}$ of skim milk at heating on milk concentrate viscosity. Int. Dairy J. 39:336-343. https://doi.org/10.1016/j.idairyj .2014.08.010.

Bouaouina, H., A. Desrumaux, C. Loisel, and J. Legrand. 2006. Functional properties of whey proteins as affected by dynamic highpressure treatment. Int. Dairy J. 16:275-284. https://doi.org/10 .1016/j.idairyj.2005.05.004.

Brisson, G. 2022. Journal of Dairy Science Article de Serine. Mendeley Data, V2. https://doi.org/10.17632/g6zj5dfrm3.2.

Broyard, C., and F. Gaucheron. 2015. Modifications of structures and functions of caseins: A scientific and technological challenge. Dairy Sci. Technol. 95:831-862. https://doi.org/10.1007/s13594-015 -0220-y.

Chen, G. Q., T. S. H. Leong, S. E. Kentish, M. Ashokkumar, and G. J. O. Martin. 2019. Chapter 8 - Membrane separations in the dairy industry. Pages 267-304 in Separation of Functional Molecules in Food by Membrane Technology. C. M. Galanakis, ed. Academic Press.

Chevalier-Lucia, D., C. Blayo, A. Gracia-Julia, L. Picart-Palmade, and E. Dumay. 2011. Processing of phosphocasein dispersions by dynamic high pressure: Effects on the dispersion physico-chemical characteristics and the binding of alpha-tocopherol acetate to casein micelles. Innov. Food Sci. Emerg. Technol. 12:416-425. https: //doi.org/10.1016/j.ifset.2011.07.007.

Corredig, M., and D. G. Dalgleish. 1996. Effect of temperature and $\mathrm{pH}$ on the interactions of whey proteins with casein micelles in skim milk. Food Res. Int. 29:49-55. https://doi.org/10.1016/0963 -9969(95)00058-5.

Corredig, M., and D. G. Dalgleish. 1999. The mechanisms of the heat-induced interaction of whey proteins with casein micelles in milk. Int. Dairy J. 9:233-236. https://doi.org/10.1016/S0958 -6946(99)00066-7.

Dumay, E., D. Chevalier-Lucia, L. Picart-Palmade, A. Benzaria, A. Gràcia-Julià, and C. Blayo. 2013. Technological aspects and potential applications of (ultra) high-pressure homogenisation. Trends Food Sci. Technol. 31:13-26. https://doi.org/10.1016/j.tifs.2012.03 .005 .

Fox, P. F., and A. Brodkorb. 2008. The casein micelle: Historical aspects, current concepts and significance. Int. Dairy J. 18:677-684. https://doi.org/10.1016/j.idairyj.2008.03.002.

Goulding, D. A., P. F. Fox, and J. A. O'Mahony. 2020. Chapter 2 Milk proteins: An overview. Pages 21-98 in Milk Proteins. 3rd ed. M. Boland and H. Singh, ed. Academic Press.

Hayes, M. G., and A. L. Kelly. 2003. High pressure homogenisation of raw whole bovine milk (a) effects on fat globule size and other properties. J. Dairy Res. 70:297-305. https://doi.org/10.1017/ S0022029903006320.

Huppertz, T., B. Vaia, and M. A. Smiddy. 2008. Reformation of casein particles from alkaline-disrupted casein micelles. J. Dairy Res. 75:44-47. https://doi.org/10.1017/S0022029907002956.

Liu, Y., and R. Guo. 2008. pH-dependent structures and properties of casein micelles. Biophys. Chem. 136:67-73. https://doi.org/10 .1016/j.bpc.2008.03.012.

Lodaite, K., F. Chevalier, E. Armaforte, and A. L. Kelly. 2009. Effect of high-pressure homogenisation on rheological properties of rennet-induced skim milk and standardised milk gels. J. Dairy Res. 76:294-300. https://doi.org/10.1017/S0022029909004117. 
Lowry, O. H., N. J. Rosebrough, A. L. Farr, and R. J. Randall. 1951. Protein measurement with the Folin phenol reagent. J. Biol. Chem. 193:265-275. https://doi.org/10.1016/S0021-9258(19)52451-6.

Madadlou, A., M. E. Mousavi, Z. Emam-djomeh, M. Ehsani, and D. Sheehan. 2009a. Sonodisruption of re-assembled casein micelles at different $\mathrm{pH}$ values. Ultrason. Sonochem. 16:644-648. https://doi .org/10.1016/j.ultsonch.2008.12.018.

Madadlou, A., M. E. Mousavi, Z. Emam-Djomeh, D. Sheehan, and M. Ehsani. 2009b. Alkaline pH does not disrupt re-assembled casein micelles. Food Chem. 116:929-932. https://doi.org/10.1016/j .foodchem.2009.03.048.

Marciniak, A., S. Suwal, G. Brisson, M. Britten, Y. Pouliot, and A. Doyen. 2018. Studying a chaperone-like effect of beta-casein on pressure-induced aggregation of beta-lactoglobulin in the presence of alpha-lactalbumin. Food Hydrocoll. 84:9-15. https://doi.org/10 .1016/j.foodhyd.2018.05.038

McMahon, D. J., and B. S. Oommen. 2008. Supramolecular structure of the casein micelle. J. Dairy Sci. 91:1709-1721. https://doi.org/ 10.3168/jds.2007-0819.

Patrignani, F., and R. Lanciotti. 2016. Applications of high and ultra high pressure homogenization for food safety. Front. Microbiol. 7:1132. https://doi.org/10.3389/fmicb.2016.01132.

Pelegrine, D. H. G., and C. A. Gasparetto. 2005. Whey proteins solubility as function of temperature and pH. Lebensm. Wiss. Technol. 38:77-80. https://doi.org/10.1016/j.lwt.2004.03.013.

Post, A. E., B. Arnold, J. Weiss, and J. Hinrichs. 2012. Effect of temperature and $\mathrm{pH}$ on the solubility of caseins: Environmental influences on the dissociation of alpha(S)- and beta-casein. J. Dairy Sci. 95:1603-1616. https://doi.org/10.3168/jds.2011-4641.

Regnault, S., E. Dumay, and J. C. Cheftel. 2006. Pressurisation of raw skim milk and of a dispersion of phosphocaseinate at $9{ }^{\circ} \mathrm{C}$ or 20 ${ }^{\circ} \mathrm{C}$ : Effects on the distribution of minerals and proteins between colloidal and soluble phases. J. Dairy Res. 73:91-100. https://doi .org/10.1017/S0022029905001494.

Rynne, N. M., T. P. Beresford, A. L. Kelly, and T. P. Guinee. 2004. Effect of milk pasteurization temperature and in situ whey protein denaturation on the composition, texture and heat-induced functionality of half-fat Cheddar cheese. Int. Dairy J. 14:989-1001. https://doi.org/10.1016/j.idairyj.2004.03.010.

Sandra, S., and D. G. Dalgleish. 2005. Effects of ultra-high-pressure homogenization and heating on structural properties of casein mi- celles in reconstituted skim milk powder. Int. Dairy J. 15:10951104. https://doi.org/10.1016/j.idairyj.2004.11.015.

Sinaga, H., N. Bansal, and B. Bhandari. 2017. Effects of milk pH alteration on casein micelle size and gelation properties of milk. Int. J. Food Prop. 20:179-197. https://doi.org/10.1080/10942912 .2016.1152480.

Tan, C. P., and M. Nakajima. 2005. $\beta$-Carotene nanodispersions: Preparation, characterization and stability evaluation. Food Chem. 92:661-671. https://doi.org/10.1016/j.foodchem.2004.08.044.

Vaia, B., M. A. Smiddy, A. L. Kelly, and T. Huppertz. 2006. Solventmediated disruption of bovine casein micelles at alkaline $\mathrm{pH}$. J. Agric. Food Chem. 54:8288-8293. https://doi.org/10.1021/jf061417c.

Vandijk, H. J. M. 1992. The properties of casein micelles. 6. Behavior above $\mathrm{pH}-9$, and implications for the micelle model. Neth. Milk Dairy J. 46:101-113.

Zamora, A., V. Ferragut, P. D. Jaramillo, B. Guamis, and A. J. Trujillo. 2007. Effects of ultra-high pressure homogenization on the cheese-making properties of milk. J. Dairy Sci. 90:13-23. https:// doi.org/10.3168/jds.S0022-0302(07)72604-8.

Zamora, A., V. Ferragut, J. M. Quevedo, B. Guamis, and A. J. Trujillo. 2012. Ultra-high pressure homogenisation of milk: Technological aspects of cheese-making and microbial shelf life of a starter-free fresh cheese. J. Dairy Res. 79:168-175. https://doi.org/10 $.1017 /$ S0022029912000052.

Zamora, A., and B. Guamis. 2015. Opportunities for ultra-high-pressure homogenisation (UHPH) for the food industry. Food Eng. Rev. 7:130-142. https://doi.org/10.1007/s12393-014-9097-4.

Zouari, A., V. Briard-Bion, F. Gaucheron, P. Schuck, C. Gaiani, M. Triki, H. Attia, and M. A. Ayadi. 2020. Effect of pH on the physicochemical characteristics and the surface chemical composition of camel and bovine whey protein's powders. Food Chem. 333:127514. https://doi.org/10.1016/j.foodchem.2020.127514.

\section{ORCIDS}

A. Doyen () https://orcid.org/0000-0001-9293-8036

G. Brisson ๑ https://orcid.org/0000-0003-1830-3002 